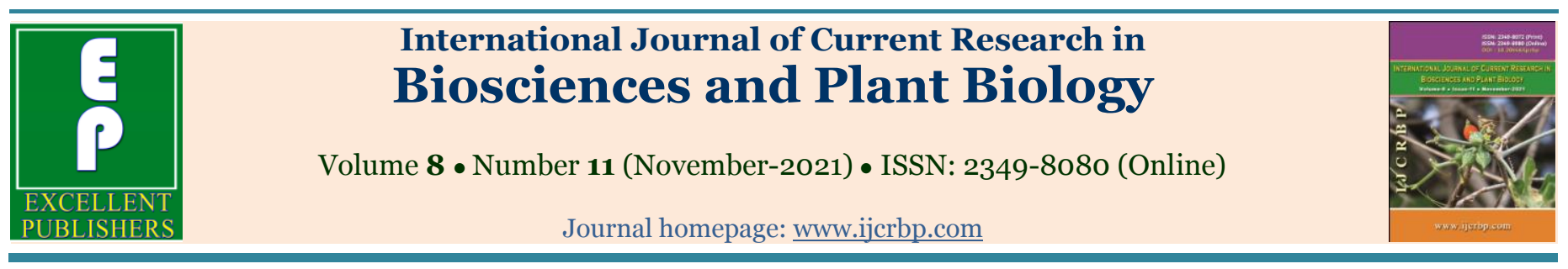

Original Research Article

doi: https://doi.org/10.20546/ijcrbp.2021.811.003

\title{
Evaluation of some heavy metal residues content in hen's table eggs marketed in Egypt
}

\author{
Maria Ahmed El-Ansary (iD)*
}

Food Control Department, Faculty of Veterinary Medicine, Alexandria University, Egypt

*Corresponding author; e-mail: mariaelansary@yahoo.com

\begin{tabular}{|c|c|}
\hline Article Info & Abstract \\
\hline $\begin{array}{l}\text { Keywords: } \\
\text { Cadmium } \\
\text { Hen's egg } \\
\text { Lead } \\
\text { Toxic heavy metals }\end{array}$ & $\begin{array}{l}\text { In the present study, } 120 \text { fresh hen's egg samples (Balady and farm) were randomly collected from } \\
\text { supermarkets of Alexandria and El-Behera Governorates, Egypt and analyzed for lead and Cadmium } \\
\text { residues expressed in }\left(\mu \mathrm{g} \mathrm{kg}^{-1}\right) \text { in egg content using atomic absorption Spectrophotometer device. } \\
\text { Results revealed that the total mean concentrations of Cd was } 0.23 \pm 0.0122\left(\mu \mathrm{kg}^{-1}\right) \text { and the total } \\
\text { mean concentration of lead was } 123.45 \pm 14.597\left(\mu \mathrm{gg}^{-1}\right) \text {. Results also revealed that the residues of } \\
\text { Cadmium in all examined samples were within the permissible limit }\left(0.05 \mathrm{mg} \mathrm{k}^{-1}\right) \text { and lead }(\mathrm{Pb}) \\
\text { concentrations exceeded the MRL value of }(0.1 \mathrm{mg} \mathrm{kg}) \text { in } 7 / 120(5.83 \%) \text { of the total examined eggs. } \\
\text { Lead contamination of hen's eggs represents a potential public health hazard, especially to children } \\
\text { repeatedly consuming eggs from contaminated hen's eggs. The public health hazard and adverse } \\
\text { outcomes of the examined toxic heavy metals on human consumers were discussed. Appropriate } \\
\text { precautions are warranted to minimize the heavy metal consumption contamination especially of lead. }\end{array}$ \\
\hline
\end{tabular}

- Received: 23 August 2021 • Revised: 03 October 2021 • Accepted: 15 October 2021 • Published Online: 6 November 2021

\section{Introduction}

Eggs are among the most nutritious foods on earth and can be part of a healthy diet. In Egypt, eggs are one of the important protein resources. Eggs represent about $1.32 \%$ of the total daily protein for an individual as sources of animal protein in Egypt. In 2016 Annual per capita consumption of egg was 94 eggs/ capita/ year (CAPMAS, 2018) in Egypt. Eggs are generally consumed by different income classes, and contamination of eggs can constitute problems to the general population. Hen's eggs could be contaminated by toxic heavy metals due to industrial waste, geochemical structures and agricultural activities is a serious problem for environmental and human health. Birds have served as bio indicator for a number of environmental contaminants predominantly heavy metals (O'Connell and Jackson, 2000). Heavy metals can be transmitted from poultry to eggs through environmental pollution or via the food chain (Giri and Singh, 2019). Some of the heavy metals that are known as potentially toxic include cadmium and lead; toxic elements can be harmful even at low concentrations when ingested over a long period of time. $\mathrm{Cd}$ and $\mathrm{Pb}$ toxic heavy metals when ingested in sufficient quantities, has been associated with adverse human health effects, potentially including carcinogenesis, neurotoxicity, nephrotoxicity and reproductive issues (Wallace et al., 2020). 
Generally, increasing the intake of toxic elements poses hazards to both animals and humans. It is therefore necessary to estimate the risks associated with the regular consumption of such eggs as well as the need for more elaborate studies to estimate their impact in respect to possible health effects. Therefore, the present study was considered in order to assess the level of two elements recognized as toxic heavy metals $\mathrm{Cd}$, and $\mathrm{Pb}$, in the hen's eggs from different locations in Alexandria and El-Behera Governorates, Egypt with a view of providing information about the risk associated with their consumption

\section{Materials and methods}

\section{Sampling}

One hundred and twenty eggs of local hens (sixty each of Balady and farm eggs) were collected from two sectors representing two geographic areas in Egypt. These sectors were: Alexandria Governorate and ElBehera Governorate; sixty eggs (30 Balady and 30 farm eggs) were purchased from the local market in each Governorate.

\section{Egg preparation and analysis}

To analyze the metals in egg content according to method previously described by AOAC, (2005) the eggs were washed vigorously with de ionized water, then opened carefully; by cut in the air cell end using pointed forceps and dissecting scissors; the eggshell was separated from egg content, the egg content were homogenized into a $50 \mathrm{~mL}$ beaker, $(10 \mathrm{~g})$ of the homogenized samples were weighed accurately in a tarred silica dish. After that the samples were dried at $120^{\circ} \mathrm{C}$ in a laboratory oven. These dishes were then placed in the muffle furnace at ambient temperature and slowly raised temperature to $450^{\circ} \mathrm{C}$ at a rate of $50^{\circ} \mathrm{C} / \mathrm{h}$. The samples were ignited in a Muffle furnace at $450^{\circ} \mathrm{C}$ for at least 8 hrs. Precaution was taken to avoid losses by volatilization of elements. After cooling the dishes of the samples were removed from furnace. Then samples were digested in desired amount of 50\% nitric acid on hot plate. After that the samples were filtrated into a $100 \mathrm{ml}$ volumetric flask using Whatman No. 44 filter paper and washed the residue.

Concentration of metals were determined and measured by an atomic absorption Spectrophotometer according to the AOAC, (2005) and calculated against a standard curve. Each analysis was carried in duplicate, standard and blank samples were analyzed every 20 sample. All concentration was expressed in $\mu \mathrm{g}$ $\mathrm{kg}^{-1}$ on dry weight basis.

\section{Standard preparation}

Metal standard solution was prepared for calibration of the instrument for each element being determined. All samples were prepared by the chemicals of analytical grade with distilled water. (1) Lead Standard solution$1 \mathrm{mg} / \mathrm{ml} .1 .000 \mathrm{~g}$ Lead was dissolved in $7 \mathrm{ml}$ conc HNO3 in 1 litre volumetric flask. Diluted to volume with water. (2) Cadmium Standard solution $1 \mathrm{mg} / \mathrm{ml}$. $1.000 \mathrm{~g}$ cadmium was dissolved in $14 \mathrm{ml}$ water and 7 $\mathrm{ml}$ conc HNO3 in 1 litre flask. Diluted to volume with water. The apparatus was adjusted at wave lengths of $217.0 \mathrm{~nm}$ for lead and $228.8 \mathrm{~nm}$ for cadmium.

\section{Analysis of samples}

Atomic Absorption Spectrophotometer was setting up with flame condition and absorbance was optimized for the analyses. Then blanks (deionized water), standards, sample blank and samples were aspirated into the flame in AAS. The calibration curves obtained for concentration vs. absorbance.

For potential health risk assessment, in the first step human health risks, posed by chronic exposure to heavy metals, were evaluated in accordance with Equation (1) (Guo et al., 2016).

Estimated daily intake (EDI) of heavy metal contaminants through egg consumption depends on heavy metal concentrations in the egg content, daily egg consumption, and consumer body weight, which is obtained using the following formula:

$$
\operatorname{EDI}(\mathrm{mg})=\frac{C \times 1 R d \times C f \text { actor }}{b w} \quad \text { Equation (1) }
$$

Where,

$C$ is a heavy metal concentration ( $\mathrm{mg} \mathrm{kg}$ wet weight) in the egg content, $I R d$ is a daily egg intake (11.64 g per day in 2016 Annual Per Capita Consumption of egg was 94 eggs/ capita/ year or (4.15 kg eggs /capita/year). (CAPMAS, 2018) in Egypt.), conversion factor (0.085) and bw is the average body weight of a normal adult was considered $65 \mathrm{~kg}$ and for child was considered $27 \mathrm{~kg}$. 
In the second step, the Health Risk Index (HRI) for local population through egg consumption was assessed, using the Equation (2) (Guo et al., 2016).

$$
H R I=\frac{E D I}{R f D} \quad \text { Equation (2) }
$$

Where,

EDI and RfD indicate the daily metal intake (mg) and reference dose of the metal $(\mathrm{mg} / \mathrm{kg} /$ day $)$, respectively. The oral reference doses were 0.0035 and 0.001 for $\mathrm{Pb}$ and Cd; respectively. When below 1 , HRI means that the exposed population is assumed to be safe. Total HRI (THRI) of heavy metals for the eggs was calculated, according to Equation (3) (Guo et al., 2016).

$$
\text { THRI= HRI (toxicant 1) + HRI (toxicant 2) Equation (3) }
$$

\section{Statistical analysis}

The statistical analysis was performed using SPSS (Statistical Package for Social Sciences) Software, Version 21. The descriptive statistics (mean values, standard error of mean) for values of egg content was analyzed. The level of significance for the differences was set at $<0.005$ and $<0.001$.

\section{Results and discussion}

In the present study, the toxic heavy metals Cadmium $(\mathrm{Cd})$ and Lead $(\mathrm{Pb})$ concentration were estimated, in whole hen's egg content. The concentrations of toxic heavy metals $\mathrm{Cd}$ and $\mathrm{Pb}$ were determined in two varieties of hen's egg (Balady and farm) collected from two wholesale markets of Alexandria and El-Behera Governorates; Egypt and summarized in Tables 1, 2 and 3. Results illustrated in Table 1 showed that the incidence of cadmium in Balady hen's eggs was 5 (16.67\%) and in farm hen's eggs was $7(23.33 \%)$ the concentration of Cd ranged from 0.1170 to $0.2620\left(\mu \mathrm{g} \mathrm{kg}^{-1}\right)$ with mean value of $0.1789 \pm 0.0087\left(\mu \mathrm{g} \mathrm{kg}^{-1}\right)$ from Alexandria Governorate (Table 1), and the incidence of $\mathrm{Cd}$ was 4 $(13.33 \%)$ with concentration ranged from 0.10 to 0.19 $\left(\mu \mathrm{g} \mathrm{kg}^{-1}\right)$ with mean value of $0.144 \pm 0.0047\left(\mu \mathrm{g} \mathrm{kg}^{-1}\right)$ in examined Balady hen's egg from El-Behera Governorate.

Table 1. Heavy metals Cadmium $\left(\mu \mathrm{g} \mathrm{kg}^{-1}\right)$ concentration concentrations in eggs collected from Alexandria and El-Behera

\begin{tabular}{|c|c|c|c|c|c|c|}
\hline \multirow{3}{*}{ Egg/district } & \multirow{3}{*}{$\begin{array}{l}\text { No. of } \\
\text { examined } \\
\text { egg samples }\end{array}$} & \multicolumn{5}{|c|}{ Cadmium $\left(\mu \mathrm{g} \mathrm{kg}^{-1}\right)$ concentration } \\
\hline & & \multicolumn{2}{|c|}{ No. of + ve samples } & \multirow{2}{*}{ Min. } & \multirow{2}{*}{ Max. } & \multirow{2}{*}{ Mean \pm SEM } \\
\hline & & No. & $\%$ & & & \\
\hline Alexandria Governorate & 30 & 5 & 16.67 & 0.1170 & 0.2620 & $0.1789 \pm 0.0087$ \\
\hline \multicolumn{7}{|l|}{ Balady hen's egg } \\
\hline Farm hen's egg & 30 & 7 & 23.33 & 0.1160 & 0.6260 & $0.2017 \pm 0.0171$ \\
\hline El Behera Governorate & 30 & 4 & 13.33 & & 0.19 & $0.144 \pm 0.0047$ \\
\hline \multicolumn{7}{|l|}{ Balady hen's egg } \\
\hline Farm hen's egg & 30 & 6 & 20 & 0.21 & 0.81 & $0.395 \pm 0.0272$ \\
\hline $\begin{array}{l}\text { Total concentration of } \mathrm{Cd} \\
\left(\mu \mathrm{g} \mathrm{kg}^{-1}\right) \text { in all examined } \\
\text { eggs }\end{array}$ & 120 & $22 / 120$ & $(18.33 \%)$ & 0.10 & 0.81 & $0.23 \pm 0.0122$ \\
\hline
\end{tabular}
Governorates, Egypt.

Cd concentrations in Balady hen's egg from El- Behera Governorate were significantly lower than Balady hen's egg from Alexandria Governorate. From the finding presented in Table 1 it is clear that the incidence of $\mathrm{Cd}$ was $7(23.33 \%)$ and $6(20 \%)$ in farm hen's eggs from Alexandria and El-Behera Governorate; respectively. Cadmium $\left(\mu \mathrm{g} \mathrm{kg}^{-1}\right)$ concentrations ranged from 0.1160 to $0.6260\left(\mu \mathrm{g} \mathrm{kg}^{-1}\right)$ and 0.21 to $0.81\left(\mu \mathrm{g} \mathrm{kg}^{-1}\right)$ with mean value of $0.2017 \pm 0.0171$ and $0.395 \pm 0.0272\left(\mu \mathrm{g} \mathrm{kg}^{-1}\right)$; respectively in examined farm hen's eggs collected from Alexandria and El-Behera Governorates. The total concentration of $\mathrm{Cd}$ ranged from 0.1 to $\left.0.81(\mu \mathrm{g} \mathrm{kg})^{-1}\right)$ with mean value of $0.230 .0122\left(\mu \mathrm{g} \mathrm{kg}^{-1}\right)$ in all examined eggs.

The differences in $\mathrm{Cd}$ concentration between the farms hen's eggs and Balady hens egg were found to be statistically significant $(\mathrm{p}<0.001)$; The concentrations of $\mathrm{Cd}$ from examined farm hen's egg from El-Behera were significantly higher than those from Alexandria farm 
hen's egg. The level of $\mathrm{Cd}$ concentration was highest in Farm hen's eggs from El-Behera Governorate. The result of $\mathrm{Cd}$ contents in egg samples obtained in this study were lower than those obtained by Aliu et al. (2021) they reported (0.29-35.42 $\left.\mu \mathrm{g} \mathrm{kg} \mathrm{k}^{-1}\right)$ with mean value of $\left(2.18 \pm 2.57 \mu \mathrm{g} \mathrm{kg}^{-1}\right)$ in eggs from Kosovo and higher than Saad Eldin and Raslan (2018) they reported that the residual concentrations of $\mathrm{Cd}$ was $(0.18 \pm 0.02)$ in eggs from Sharkia Governorate, Egypt and Kabir and Bhuyan (2019) they reported that the cadmium concentrations was recorded below the detection limit $(\mathrm{ND}(<0.003)$ in hens egg. Toxic elements such as $\mathrm{Pb}$ and $\mathrm{Cd}$ are known to be toxic and have maximum limits by European Commission in some foods but not for eggs (European Commission Regulation, EC No 1881, 2006).
Regarding the permissible limits of $\mathrm{Cd}$ it was clear that from results presented in Table 3, the mean concentrations of $\mathrm{Cd}$ in the entire examined hen's eggs were $\left(0.23 \pm 0.0122 \mu \mathrm{g} \mathrm{kg}^{-1}\right)$ which was below the maximum acceptable limits $\left(0.05 \mathrm{mg} \mathrm{kg}^{-1}\right)$ in food recommended by EU, 2006); Lower findings were reported by Saad El Din and Raslan (2018), the study recorded the mean $\mathrm{Cd}$ concentrations in the examined egg samples were $0.18 \pm 0.02,0.09 \pm 0.01 \mathrm{ppm}$ in balady hen eggs. Lower results also were reported by Korish and Attia (2020); they reported undetectable level of Cadmium in chicken eggs from Saudi Arabia. $\mathrm{Cd}$ had been linked to skeletal damage (Jarup, 2003), and $\mathrm{Cd}$ and $\mathrm{Pb}$ are known to harm the reproductive system and embryonic development.

Table 2. Heavy metal (Lead, $\mu \mathrm{g} / \mathrm{kg}^{-1}$ ) concentration concentrations in eggs collected from Alexandria and El-Behera Governorates, Egypt.

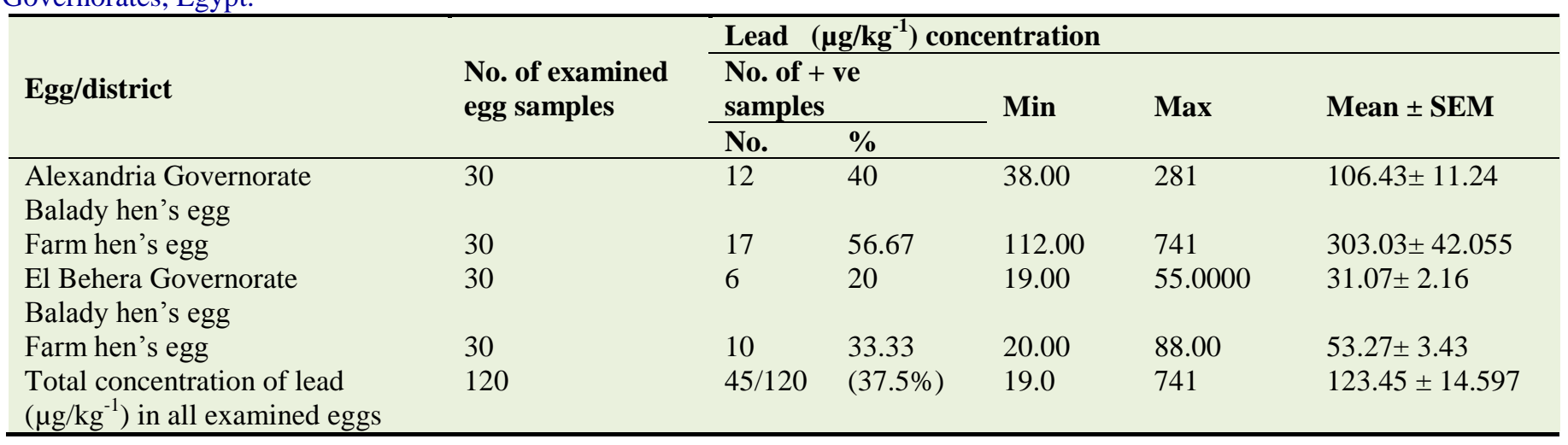

Table 3. Compliance of examined eggs samples to maximum permissible limits of toxic metals in food.

\begin{tabular}{|c|c|c|c|c|c|c|c|}
\hline Element & $\begin{array}{l}\text { No of } \\
\text { examined } \\
\text { samples }\end{array}$ & $\begin{array}{l}\text { Positive } \\
\text { samples No } \\
(\%)\end{array}$ & Min. & Max. & $\begin{array}{l}\text { Mean } \pm \text { SEM } \\
\left(\mu \mathrm{g} / \mathrm{kg}^{-1}\right)\end{array}$ & Permissible limit & $\begin{array}{l}\text { Over permissible } \\
\text { limits } \\
\text { No. }(\%)\end{array}$ \\
\hline Cadmium & 120 & $\begin{array}{l}22 / 120 \\
(18.33 \%)\end{array}$ & 0.10 & 0.81 & $0.23 \pm 0.0122$ & $\begin{array}{l}0.05(\mathrm{mg} / \mathrm{kg}) \\
\text { According to EC, } \\
2006 .\end{array}$ & Zero \\
\hline Lead & 120 & $45 / 120(37.5 \%)$ & 19.0 & 741 & $\begin{array}{l}123.45 \pm \\
14.597\end{array}$ & $\begin{array}{l}0.1(\mathrm{mg} / \mathrm{kg}) \\
\text { According to EC, } \\
2006 .\end{array}$ & $7 / 120(5.83 \%)$ \\
\hline
\end{tabular}

Chicken eggs may pose risks due to contamination with heavy metals from the environment or through the food chain. Chicken exposure to heavy metals is due to ingestion of repeated small doses of such chemicals via feed and water. The major component of chicken feed as grains (maize, soybean and wheat) which are the main component of feed could also accumulated metals from contaminated soil depended on location. However food is the primary source of cadmium exposure, the main source of $\mathrm{Cd}$ contamination can be attributed to the use of chemical pesticides to cultivate poultry food as well as poultry medicines, containing cadmium and its adverse health effects occur in the form of kidney damage but possibly also bone effects and fracture. The concentration of the heavy metals Lead in examined hen's eggs are presented in Table 2, it is clear that 12 out of $30(40 \%)$ Balady hen's eggs from Alexandria Governorate were found positive for lead with concentration ranged from 38 to $281\left(\mu \mathrm{g} \mathrm{kg}^{-1}\right)$ with mean value of $106.43 \pm 11.24\left(\mu \mathrm{g} \mathrm{kg}^{-1}\right)$. While in the 
analyzed Balady hen's egg samples from El-Behera Governorate the incidence of positive samples was $6 / 30$ (20\%) and the concentration of Lead was ranged from 19 to $55\left(\mu \mathrm{g} \mathrm{kg}^{-1}\right)$ with mean value of $31.07 \pm 2.16(\mu \mathrm{g}$ $\left.\mathrm{kg}^{-1}\right)$. Lead concentrations were found higher significantly in Balady hen's eggs from Alexandria than Balady hen's eggs from El-Behera Governorate. The little variation in the metal content of egg bring at different location, feed appeared to be the major contributor to the amount of metals in eggs. These results also may explain the differences in bioaccumulation of the metal content in the eggs laid by hens from industrialized and agricultural regions (Dobrzañski, et al., 2004). Regarding the Pb element from farm hen's egg, results presented in Table 2 showed that the incidence of positive samples from Alexandria Governorate was 17 /30 (56.67 \%); the lead concentration in farm eggs ranged from 112 to $741 \quad(\mu \mathrm{g}$ $\mathrm{kg}^{-1)}$ with mean value of $303.03 \pm 42.0 .055\left(\mu \mathrm{g} \mathrm{kg}^{-1}\right)$. While the lead incidence were $10 / 30$ (33.3\%) of examined farm hen's eggs from El-Behera Governorate and the minimum and maximum lead concentration were $\left(20\right.$ and $\left.88 \mu \mathrm{g} \mathrm{kg}^{-1}\right)$ with mean value of $(53.27 \pm$ $3.43 \mu \mathrm{g} \mathrm{kg}^{-1}$ ). The incidence of $\mathrm{Pb}$ was 45/120 (37.5\%) for all examined hen's eggs. The mean concentrations of $\mathrm{Pb}$ in all examined egg samples were $(123.45 \pm 14.59$ $\mu \mathrm{g} \mathrm{kg}^{-1}$ ) (Table 2). The mean concentration of lead in farm hen's eggs from Alexandria was found significantly higher than mean concentration of lead from El-Behera Governorate. The results of $\mathrm{Pb}$ content in all examined hen's eggs were found highest in concentration in farm hen's eggs from Alexandria. Higher findings were obtained by Saad Eldin, and Raslan (2018) they reported that the residual concentrations of lead exceeded the maximum permissible limits set by $(\mathrm{FAO}) /(\mathrm{WHO})$ in all the examined Balady hen's eggs $(0.34 \pm 0.03 \mathrm{ppm} / \mathrm{wet}$ weight); from Egypt. Lower results were obtained by Korish and Attia (2020) they reported undetectable level of lead in chicken eggs from Saudi Arabia.; and Faryabi et al. (2021) they reported a concentration of $0.1163 \mathrm{mg}$ $\mathrm{kg}^{-1}$ of lead in eggs from Qom, Iran. The mean concentrations of $\mathrm{Pb}$ in all examined eggs the present study were higher than those reported by Aliu et al. (2021) they recorded lead concentration range 0.04$1.41 \mu \mathrm{g} \mathrm{kg}^{-1}$ with mean value of $\left(32.92 \pm 23.18 \mu \mathrm{g} \mathrm{kg}^{-1}\right)$. The mean concentration of $\mathrm{Pb}$ in eggs from farms was significantly greater than the averages of Balady hens eggs $(p<0.001)$. There were significant differences among the concentration of the two $(\mathrm{Cd}$ and $\mathrm{Pb})$ metals included in the study between the egg samples from farms and Balady hen's eggs were observed. $\mathrm{Pb}$ concentration was the highest. The high $\mathrm{Pb}$ concentration in samples from farm hens can be explained due to the presence of the large industrialization in this region, which is also considered to be the main source of environmental pollution. EFSA (2012) reported that the environmental pollutants such as toxic element detected in free-range hen eggs that pasture outdoors are more exposed to environmental contamination were higher than those detected in battery-reared hen eggs. The levels of lead in eggs were significantly different $(P \leq 0.05)$ among the two regions. The mean values of $\mathrm{Pb}$ concentration were near the permissible limit $\left(0.1 \mathrm{mg} \mathrm{kg}^{-1}\right)$ in Balady eggs form Alexandria $\left(0.106 \mathrm{mg} \mathrm{kg}^{-1}\right)$ and lower than the permissible limit for Balady eggs $\left(0.031 \mathrm{mg} \mathrm{kg}^{-1}\right)$ and farm hens eggs from El-Behera $\left(0.053 \mathrm{mg} \mathrm{kg}{ }^{-1}\right)$ Governorates and exceeded the permissible limit in farm hens egg $\left(0.303 \mathrm{mg} \mathrm{kg}^{-1}\right)$ from Alexandria. The variation may be resulted from feeding behavior and diverse capability for birds to ingest soil and grass. Researchers also found relationship between the levels of heavy metals in chicken and their feed like plant and insect. Hens' feed (water, additives, etc.) and husbandry system are the main influencing factors governing toxic element levels in eggs. These metals can pass to the egg representing a risk factor in humans who consume contaminated hen's table eggs.

Regarding the permissible limits of $\mathrm{Pb}$, it was clear that from results presented in Table 3, 7 out of 120 examined hen's egg samples $(5.83 \%)$ exceeded the maximum acceptable limits in food $\left(0.1 \mathrm{mg} \mathrm{kg}^{-1}\right)$ recommended by EU, 2006 (Table 3). A significant difference $(P \leq 0.05)$ was observed between the mean concentration $\left(0.123 \mathrm{mg} \mathrm{kg}^{-1}\right)$ of the studied samples and the international standard lead level in eggs (0.1 $\left.\mathrm{mg} \mathrm{kg}^{-1}\right)$. Approximately $40 \%$ uptake of lead from egg is reported in children Khan et al. (2016). High lead concentration in food has been reported to be associated with cardiovascular, renal, nervous, and skeletal-system diseases (Jarup, 2003). The major sources of metal contamination in commercially produced eggs include contamination in the feed, water as well as contaminations in the environment. Poultry ration in many cases contain bone or fish meals, which are considered major sources of feed contamination with metals. Lead ingested by chicken through contaminated feed is deposited in bones; soft tissue and eggs, so the contaminated egg represents a potential public health hazard. Table 4 showed the 
estimated daily intake ( $\mathrm{mg} \mathrm{kg}^{-1}$ bw. day) of $\mathrm{Cd}$ and $\mathrm{Pb}$ heavy metals by Egyptian adults and children through consumption of hen's egg compared against (JECFA) maximum permitted daily dietary allowance per person and recommended daily allowance (RDA) for adults and children. The maximum provisional tolerance daily intake of $\mathrm{Pb}$ is based on the provisional tolerable weekly intake (PTWI) the recommended daily allowance for adults JECFA, (2009) and the maximum provisional tolerance daily intake of $\mathrm{Cd}$ is based on the provisional tolerable monthly intake (PTMI) of JECFA (Commission 2013).

Table 4. The estimated daily intake (EDI, $\mathrm{mg} / \mathrm{kg}$ bw day) of Egyptian adults and children according to mean weight of $\mathrm{Cd}$ and $\mathrm{Pb}$ toxic heavy metals in total of the examined eggs compared to the recommended daily allowance set by JECFA for adults and children.

\begin{tabular}{|c|c|c|c|c|c|}
\hline \multirow{2}{*}{$\begin{array}{l}\text { Toxic } \\
\text { heavy } \\
\text { metal }\end{array}$} & \multirow{2}{*}{$\begin{array}{l}\text { RDA } \\
\text { (mg/day } \\
\text { /person) }\end{array}$} & \multirow{2}{*}{ MTDI $(\mu \mathrm{g} / \mathrm{kg}$ bw/day $)$} & \multirow{2}{*}{ MTMI mg/kg bw. } & \multicolumn{2}{|c|}{ EDI $\left(\mathrm{mg} / \mathrm{kg}^{-1}\right.$ bw day $\left.{ }^{-1}\right)$} \\
\hline & & & & Adult & Child \\
\hline $\mathrm{Cd}$ & 0.06 & 7 & $\begin{array}{l}0.025 \mathrm{mg} / \mathrm{kg} \text { bw/month } \\
\text { JECFA (Commission 2013) }\end{array}$ & 0.000035 & 0.000084 \\
\hline $\mathrm{Pb}$ & 0.21 & $\begin{array}{l}\text { The JECFA PTDI of } \mathrm{Pb} \text { is } 3.6 \\
\mu \mathrm{g} / \mathrm{kg} \text { bw/day (WHO, 2005). } \\
(0.0036 \mathrm{mg} / \mathrm{kg})\end{array}$ & -- & 0.0019 & 0.0045 \\
\hline
\end{tabular}

RDA: Recommended daily dietary allowance, MTDI: Maximum tolerable daily intake;

MTMI: Maximum tolerable monthly intake

The EDI ( $\mathrm{mg} \mathrm{kg}^{-1}$ bw day $\left.{ }^{-1}\right)$ of Cadmium for adult was 0.000035 ; and 0.000084 for children which was lower than the PTMI (0.025 $\mathrm{mg} \mathrm{kg}^{-1} \mathrm{Bw} /$ month) JECFA (commission 2013) indicating no health risk for $\mathrm{Cd}$ through egg consumption among Egyptian consumers. The EDI ( $\mathrm{mg} \mathrm{kg}^{-1}$ bw day $\left.{ }^{-1}\right)$ of $\mathrm{Pb}$ for adult was 00.0019 and 0.0045 ( $\mathrm{mg} \mathrm{kg}^{-1}$ bw day ${ }^{-1}$ ) for lead for adult and child consumers; respectively. The JECFA (WHO, 2005) PTDI of $\mathrm{Pb}\left(0.0036 \mathrm{mg} \mathrm{kg}^{-1}\right)$. Therefore, it can be concluded that people might face no potential significant health risk through mere consumption of the analyzed eggs, under the current consumption rate except for $\mathrm{pb}$ in child consumer as it exceeded the JECFA PTDI of $\mathrm{Pb}\left(0.0036 \mathrm{mg} \mathrm{kg}^{-1}\right.$ bw day $\left.{ }^{-1}\right)$. Chronic lead exposure causes developmental abnormalities, deficits in intelligence quotient, neurotoxicity in infants, constipation, colic and anaemia and also can damage intellectual performance, resulting in reduced cognitive development in children. Young children are particularly vulnerable to lead poisoning because they absorb 4-5 times as much ingested lead as adults from a given source (WHO, 2021) no safe level of lead exposure has yet been identified for children's health. Excess lead in food can cause serious damage to the brain, kidneys, nervous system and red blood cells in human's toxic elements can be very harmful even at low concentration when ingested over a long time period.

The Health Risk Index results were showed in Table 5 assuming the weekly consumption rate of three eggs per person revealed that the Health Risk Index (HRI) for $\mathrm{Cd}$ for child was 0.0035 and was 0.00842 for adult human consuming hen's eggs was within the safe limits as the value (HRI < 1) while the HRI for $\mathrm{Pb}(0.5368)$ was within the safe limits for adult consumers (HRI < 1) and unsafe for children (1.2878) as it (HRI >1). Results also showed that the total HRI was safe (0.5403) for adult consumers and unsafe (1.2962) for children (HRI >1). The continuous intake of heavy metals through food at unsafe levels could have adverse effects in the terms of disrupting many biological and biochemical processes in humans, especially in children. Metals can bio accumulates over time to reach toxic levels, which can cause decreases in reproductive success and lowered survival (Burger, 1999). Lead is a cumulative toxicant that affects multiple body systems and is particularly harmful to young children. Drinking water delivered through lead pipes or pipes joined with lead solder may contain lead (WHO, 2021). Once lead enters the body, it is distributed to organs such as the brain, kidneys, liver and bones. At lower levels of exposure that causes no obvious symptoms, lead can affect children's brain development, causes anaemia, hypertension, renal impairment, immunotoxicity and toxicity to the reproductive organs. A regular monitoring of heavy metals in hen's eggs is recommended at an appropriate frequency to establish the true contribution of eggs to the dietary intake of heavy metals to avoid adverse toxic effects for human consumption. 
Table 5. Health Risk Index (HRI) for local population through hen's egg consumption.

\begin{tabular}{llllll}
\hline & Cd & Health risk & Pb & Health risk & Total HRI (THRI) \\
\hline Adult & 0.0035 & Safe & 0.5368 & Safe & 0.5403 \\
Child & 0.00842 & Safe & 1.2878 & Unsafe & 1.2962 \\
\hline
\end{tabular}

\section{Conclusions}

It is concluded that cadmium was found to be in the normal range reported in the literature and lead health risk through egg consumption is within safe limits for adult consumers but exceeded the permissible limit for children indicating health hazard for lead through egg consumption among Egyptian child consumers. However, the presence of toxic metals, $\mathrm{Cd}$ and $\mathrm{Pb}$ was higher in poultry farm eggs than Balady hen's eggs. The nutritional importance and high consumption of eggs among households necessitate a more careful monitoring of lead concentrations to meet public health requirements. Environment pollution with heavy metals lead to an increased attention in metal contamination of food and amongst them eggs which represent an essential part of human's diet particularly children.

\section{Conflict of interest statement}

Authors declare that they have no conflict of interest.

\section{References}

Aliu, H., Dizman, S., Sinani, A., Hodolli, G., 2021. Comparative study of heavy metal concentration in eggs originating from industrial poultry farms and free-range hens in Kosovo. J. Food Qual., 2021:Article ID 6615289, 7 p.

Association of Official Analytical Chemists (AOAC) 2005. Lead, cadmium, zinc, copper and iron in foods, Atomic Absorption Spectrometry after dry ashing. Official Method 999.11. Official Methods of Analysis of AOAC International, 18th Edn.

Burger, J., Woolfenden, G.E., Gochfeld, M., 1999. Metal concentrations in the eggs of endangered Florida scrubjays from Central Florida. Arch. Environ. Contam. Toxicol., 37: 385-338.

Dobrzañski, Z., Gürecki, H., Koacz, R., Gürecka, H., Trziszka, T., 2004. The content of heavy metals in hen eggs from farmyard rearing. Acta Sci. Pol. Ser. Zoot., 3: 249-253.

Central Agency for Public Mobilization Statistics (CAPMAS), 2018. Egypt in Figures (2018). Agriculture Annual Per Capita of Some Food Products Consumption (2013-2016), 70p.
European Commission (EC), 2006. Commission Regulation (EC) No. 1881/2006 of 19 December 2006 setting maximum levels for certain contaminants in foodstuffs. Off. J. Eur. Union (L Series): $364 / 5$

EFSA, 2012. Scientific Report-update of the monitoring of levels of dioxins and PCBs in food and feed.

Faryabi, S., Ghorbiani, M., Nazarpak, H. H., Rashidimehr, A., 2021. Lead exposure through eggs in Iran: health risk assessment. Foods Raw Mat., 9: 184- 191.

Giri, S., Singh, A. K., 2019. Heavy metals in eggs and chicken and the associated human health risk assessment in the mining areas of Singhbhum copper belt, India. Arch. Environ. Occup. Health, 74(4): 167-170.

Guo, J., Yue, T., Li, X., Yuan, Y., 2016. Heavy metal levels in kiwifruit orchard soils and trees and its potential health risk assessment in Shaanxi, China . Environ. Sci. Pollut. Res., 23(14): 14560-14566.

Jarup, L., 2003. Hazards of heavy metal contamination, Br. Med. Bull., 68: 167-182.

JECFA, 2009. Evaluations of the Joint FAO/WHO Expert Committee on Food Additives.

JECFA, 2013. Evaluations of the Joint FAO/WHO Expert Committee on Food Additives.

Kabir, A., Bhuyan, Md. S., 2019. Heavy metals in egg contents of hens (Gallus gallus domesticus) and ducks (Anas platyrhynchos) from Chittagong Region, Bangladesh. J. Poll. Effects Control, 7: 232.

Khan, Z., Sultan, A., Khan, R., Khan, S., Imranullah, Farid, K., 2016. Concentrations of heavy metals and minerals in poultry eggs and meat produced in Khyber Pakhtunkhwa, Pakistan. Meat Sci. Veter. Public Health, 1(1): 4-10.

Korish, A.M., Attia, Y. A., 2020. Evaluation of heavy metal content in feed, litter, meat, meat products, liver, and table eggs of chickens. Animals, 10: 727.

O'Connell, T.J., Jackson, L.E., Brooks, R.P., 2000. Bird guilds as indicators of ecological condition in the central Appalachians. Ecol. Appl., 10(6): 1706-1721.

Saad Eldin, W. F., Raslan, A.A., 2018. Residues of some toxic heavy metals and trace elements in chicken eggs. Zagazig Vet. J., 46: 8-16. 
Wallace, D. R., Taalab, Y. M., Heinze, S., Tariba Lovakovic, B., Pizent, A., Renieri, E., Tsatsakis, A., Farooqi, A. A., Javorac, D., Andjelkovic, M., Bulat, Z., Antonijevic, B., Buha Djordjevic, A., 2020. Toxic metal induced alteration in miRNA expression profile as a proposed mechanism for disease development. Cells, 9(4): 901.

World Health Organization, 2021. Childhood lead poisoning. Lead Poisoning Institute for Health Metrics and Evaluation (IHME), GBD Compare
Geneva (3).

World Health Organization, 2021. Evaluations of the Joint FAO/WHO Expert Committee on Food Additives (JECFA) Cadmium. Available at https://apps.who.int/food-additives-contaminantsjecfa-database/chemical.aspx?chemID $=1376$

World Health Organization, 2005. Safety evaluation of certain food additives and contaminants: Lead. Food Additives Series No. 44. FAO/WHO Expert Committee on Food additives, Geneva, Switzerland.

\section{How to cite this article:}

El-Ansary, M. A., 2021. Evaluation of some heavy metal residues content in hen's table eggs marketed in Egypt. Int.

J. Curr. Res. Biosci. Plant Biol., 8(11): 21-28. doi: https://doi.org/10.20546/ijcrbp.2021.811.003 